\title{
Artikel Review
}

\section{Beberapa Catatan Pemanfaatan 1-Methylcyclopropene Pada Krisan (Chrysanthemum morifolium Ram.)}

\author{
Ardika Albi Fauzi ${ }^{1}$, Kusumiyati ${ }^{2}$, Syariful Mubarok ${ }^{3}$, dan Fathi Rufaidah ${ }^{4}$ \\ ${ }^{1}$ Mahasiswa Agroteknologi, Fakultas Pertanian, Uiversitas Padjadjaran, Bandung \\ Email : Albiardika@gmail.com \\ 2Departeman Budidaya Pertanian, Fakultas Pertanian, Uiversitas Padjadjaran \\ Email : Kusumiyati@unpad.ac.id \\ ${ }^{3}$ Departeman Budidaya Pertanian, Fakultas Pertanian, Uiversitas Padjadjaran \\ Email : Syariful.mubarok@unpad.ac.id \\ ${ }^{4}$ Universitas BSI Bandung
}

\begin{abstract}
Chrysanthemum (Chrysanthemum morifolium Ramat) is an herbaceous perennial plant of the Asteraceae family. In Indonesia, Chrysanthemum has a fairly high economic value as potted flowers and cut flowers. Market demand for chrysanthemum growth in 2007-2013 amounted to 2.59\%. One of the factors that influence the quality of chrysanthemum cut flowers is ethylene. Ethylene is a plant hormone that plays a role in the process of abortion of leaves and flowers, flowering triggers, swelling of stems, root formation, triggers seed germination, and ripening fruit. Chrysanthemums belong to non-climacteric plants that are less sensitive to ethylene. However, in some studies found some varieties of chrysanthemum are sensitive to the exposure to exogenous ethylene. The effects of ethylene can be eliminated by the application of 1-Methylcyclopropene (1-MCP). 1-MCP is an ethylene competitor when attached to the receptor. The 1-MCP application on chrysanthemum extends the shelf life of flowers by reducing chlorophyll degradation and losing fresh weight of cut flowers. The 1-MCP application of chrysanthemum cuttings inhibits leaf yellowing, leaf abscission, and necrosis. Moreover, the applied 1-MCP sequence will be inhibited in root formation due to the associated ethylene role of root initiation. In this review, we summarize the study of 1-MCP in the postharvest treatment of chrysanthemum flower and cutting.
\end{abstract}

Keywords: Chrysanthemum, Ethylene, Senescene, 1-Methylcyclopropene, Inhibitor.

\begin{abstract}
ABSTRAK
Tanaman krisan (Chrysanthemum morifolium Ramat) merupakan tanaman perenial herbasius dari famili Asteraceae. Krisan memiliki nilai ekonomi yang cukup tinggi di Indonesia sebagai tanaman hias dalam bentuk bunga pot dan bunga potong. Permintaan pasar akan bunga krisan mengalami peningkatan setiap tahunnya.. Salah satu faktor yang mempengaruhi penurunan kualitas bunga potong krisan yakni etilen. Etilen merupakan hormon tanaman yang berperan pada proses pengguguran daun dan bunga, pemicu pembungaan, pembengkakan batang, pembentukan akar, memicu perkecambahan benih, pemasakan buah. Krisan termasuk kedalam jenis tanaman non-klimakterik, yakni tanaman yang kurang sensitif terhadap etilen. Namun pada beberapa penelitian menemukan beberapa varietas dari krisan sensitif terhadap paparan etilen eksogen. Salah satu cara untuk mengurangi efek etilen dengan aplikasi 1-Methylcyclopropene (1-MCP). Kerja 1MCP pada tanaman yakni sebagai kompetitor etilen saat menempel pada reseptor. Aplikasi 1-MCP pada bunga potong krisan dapat memperpanjang umur dari bunga dengan mengurangi degradasi klorofil dan kehilangan berat segar bunga potong. Aplikasi 1-MCP pada setek krisan mampu mengurangi gejala kerusakan akibat etilen seperti penguningan daun, pengguguran daun, dan nekrosis. Setek yang diaplikasikan 1-MCP akan mengalami penghambatan dalam pembentukan akar karena terkait peran etilen terhadap inisiasi akar.
\end{abstract}

Kata kunci: Krisan, Etilen, Senesens, 1-Methylcyclopropene, Inhibitor 


\section{Pendahuluan}

Hormon etilen menjadi salah satu faktor yang mempengaruhi pelayuan dan penurunan kualitas produk pertanian. Etilen $\left(\mathrm{C}_{2} \mathrm{H}_{4}\right)$ merupakan hormon tanaman yang berperan terhadap proses perkembangan dan penuaan pada tanaman. Etilen menyebabkan respon pada tanaman seperti pengguguran daun dan bunga, pemicu pembungaan, pembengkakan batang, pembentukan akar, memicu perkecambahan benih, dan pemasakan buah (lqbal et al., 2017; Bleecker dan Kende, 2000). Pengaruh etilen dipengaruhi oleh sensitifitas komoditas terhadap etilen, konsentrasi etilen, dan lama paparan etilen.

Banyak ditemukan penelitian mengenai bahan kimia yang mampu mengurangi produksi etilen pada tanaman serta mengurangi efek dari etilen terhadap tanaman. Dimulai dari penghambatan produksi ACC sintase yang merupakan proses awal dari biosintesis etilen hingga penghambatan etilen pada saat menempel pada reseptor di sel tanaman (Serek et al., 2006). 1-Methylcyclopropene (1-MCP) diketahui berfungsi sebagai etilen inhibitor pada tingkat reseptor.

Salaun dan Baird (1995) menyatakan 1-MCP merupakan produk yang lebih aman dibandingkan dengan bahan kimia dengan kerja serupa seperti perak thiosulfat (STS). 1MCP dapat diaplikasikan pada produk pertanian yang dikonsumi. Howe dan Dobson (2002) menyatakan penggunaan perak thiosulfat sangat dibatasi terlebih pada produk yang dikonsumsi mengingat bahan ini berasal dari logam. Kerja 1-Methylcyclopropene (1MCP) dalam mengurangi pengaruh etilen pada tanaman yakni dengan menjadi kompetitor etilen saat menempel pada reseptor (Mirjalili, 2015).

Pengaruh 1-MCP terhadap komoditas sayur, buah, dan tanaman hias telah banyak ditemukan (Blankenship, 2001; Watkins, 2006). Penggunaan 1-MCP tercatat pengaruhnya untuk mempertahankan kualitas bunga potong dan setek krisan (Chrysanthemum morifolium Ramat). Krisan merupakan jenis tanaman hias bunga yang populer di dunia khususnya di Indonesia. Krisan merupakan tanaman hias yang cukup penting kedua di dunia setelah mawar (Silva, 2003). Tanaman herbasius ini memiliki nilai ekonomi yang cukup tinggi sebagai tanaman hias (Pusat Data dan Sistem Informasi Pertanian, 2014). Penggunaan 1-MCP mampu mengurangi efek etilen endogen atau eksogen. Penggunaan 1-MCP tidak menurunkan produksi etilen pada tanaman namun menjadi inhibitor dalam penempelan di reseptor, sehingga etilen tidak dapat mempengaruhi fisiologis tanaman (Blankenship, 2001).

\section{1-Methylcyclopropene Sebagai Etilen Inhibitor Pada Tingkat Reseptor}

Etilen dapat bersumber dari tanaman itu sendiri yang disebut etilen endogen ataupun bersumber bukan dari tanaman tersebut (etilen eksogen). Etilen eksogen dapat 
dihasilkan dari berbagai sumber seperti dari buah atau bagian tanaman lain yang telah matang, asap dari suatu mesin seperti kendaraan bermotor, asap rokok, atau kegiatan pengelasan logam (Blankenship, 2001). Untuk menampilkan suatu respon, senyawa etilen perlu melalui proses penempelan pada reseptor ligand berupa asam lemak yang berada di bagian tanaman tepatnya di bagian retikulum endoplasma. Penempelan senyawa etilen pada reseptor akan memberikan sinyal untuk terjadinya suatu efek fisiologis (Setyadjit et al.,2012).

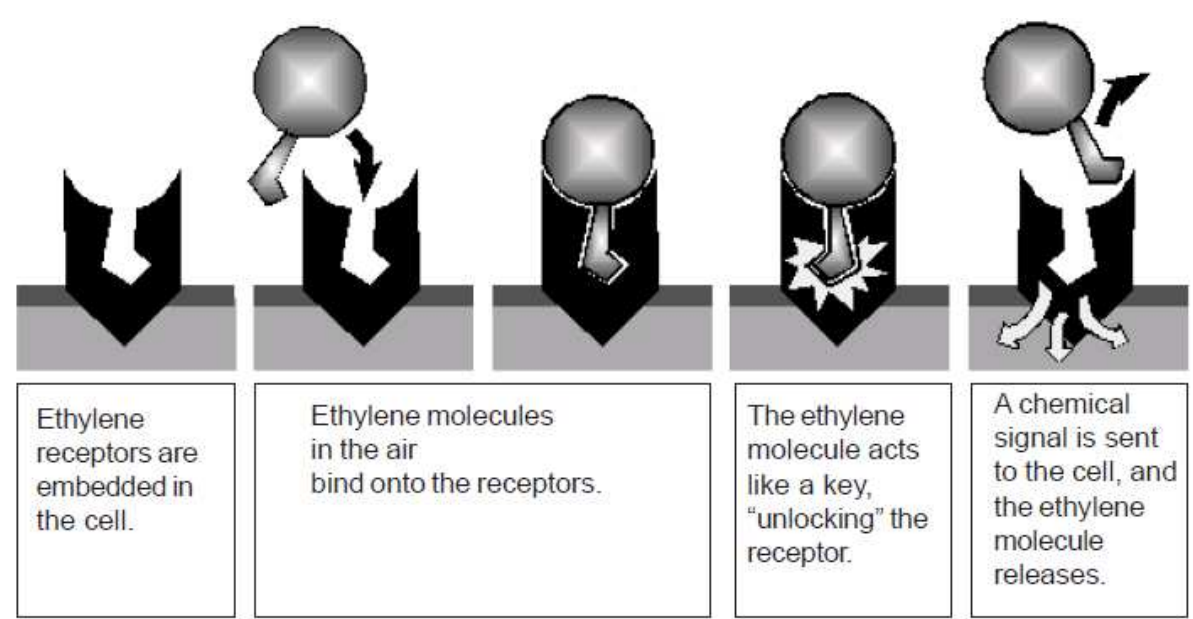

Gambar 1. Mekanisme kerja etilen dalam menghasilkan efek fisiologis (Blankenship, 2001)

1-Methylcyclopropene (1-MCP) merupakan suatu bahan yang digunakan untuk menghambat kerja etilen dalam memberikan efek fisiologis pada tanaman. 1-MCP memiliki mekanisme menjadi kompetitor etilen dalam proses binding atau proses penempelan etilen pada reseptor ligand pada permukaan jaringan tanaman yang pada akhirnya akan memberikan efek fisiologis pada tanaman (Blankenship, 2001). 1-MCP ini pada awal ditemukannya, 1-MCP ini dihasilkan dari serangkaian proses pengolahan dari bahan Diazocyclopentadiene (DACP). 1-MCP diaplikasikan dalam bentuk gas (Sisler dan Blankenship, 1996).

Terdapat beberapa faktor yang mempengaruhi efek penggunaan 1-MCP antara lain jenis komoditas, tingkat perkembangan dari tanaman, konsentrasi 1-MCP, temperatur lingkungan saat aplikasi, dan lama aplikasi 1-MCP (Blankenship, 2001). 1-MCP umumnya diaplikasikan pada konsentrasi yang rendah yakni $2,5 \mathrm{nl}^{-1}$ hingga $1 \mu \mathrm{l}^{-1}$. Lama aplikasi 1-MCP umumnya dilakukan pada rentang waktu 12-24 jam dengan suhu ruang aplikasi $20-25^{\circ} \mathrm{C}$ (Blankenship dan Dole, 2003).

Efektivitas 1-MCP dipengaruhi oleh beberapa faktor antara lain konsentrasi dan lamanya aplikasi. Sudah banyak penelitian untuk melihat efektivitas 1-MCP pada berbagai tanaman hias seperti geranium, mawar dan jenis tanaman hias lainnya (Afiifah et al., 2017; Blankenship, 2001; Mubarok et al, 2011). Penggunaan 1-MCP telah diketahui 
pengaruhnya pada beberapa jenis komoditas sayur dan buah (Tabel 2.). Saat 1-MCP menempel pada reseptor, proses penempelan tersebut bersifat permanen sehingga etilen tidak mendapatkan celah untuk menempel pada reseptor. Namun begitu, sensitivitas tanaman terhadap etilen bisa kembali normal dengan membentuk tempat penempelan baru bagi etilen untuk menghasilkan respon fisiologis (Feng et al.,2004).

Tabel 1. Penggunaan bahan kimia, rekayasa lingkungan dan rekayasa molekuler untuk menghambat setiap tahap kerja etilen

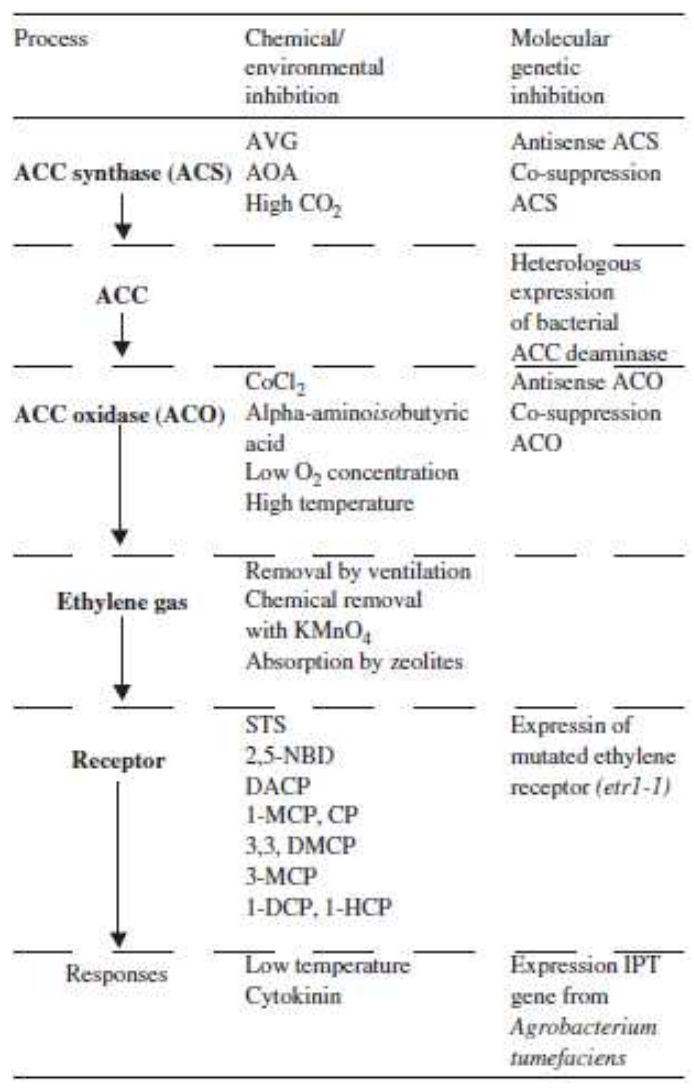

Sumber : (Serek et al, 2006)

\section{Aplikasi 1-Methylcyclopropene Memperpanjang Umur Segar Krisan}

Aplikasi 1-MCP pada bunga potong krisan. Beberapa penelitian mengungkapkan penggunaan 1-MCP pada krisan. Pada penelitian Burana et al. (2015), aplikasi 1-MCP $0.1 \mu \mathrm{L} . \mathrm{L}^{-1}$ selama 6 jam tidak memberikan pengaruh yang berbeda nyata dalam memperpanjang umur bunga potong krisan. Hasil penelitian ini mengindikasikan bahwa krisan tidak terlalu sensitif terhadap etilen. Krisan termasuk kedalam jenis tanaman non-klimaterik, dengan kata lain pengaruh etilen sangat kecil terhadap kerusakan fisiologis selama penuaan bagian tanaman (Silva, 2006). Narumi et al. (2005) menemukan pada beberapa varietas dari Chrysanthemum morifolium sensitif terhadap paparan etilen eksogen. Permasalahan pada penyimpanan dan pengangkutan bunga potong atau setek krisan yang rentan rusak akibat paparan etilen eksogen dapat terjadi karena sumber etilen eksogen mudah ditemukan di lingkungan umum. Hasil berbeda 
ISSN 2549-7383 (online)

ISSN 2354-7251 (print)

ditemukan Penelitian Fahmy dan Hassan (2005) bahwa aplikasi 1-MCP konsentrasi 0,3 $\mu \mathrm{L} . \mathrm{L}^{-1} ; 0,5 \mu \mathrm{L} . \mathrm{L}^{-1}$ dan $0,7 \mu \mathrm{L} . \mathrm{L}^{-1}$ dengan waktu aplikasi selama 3 dan 6 jam mampu memperpanjang umur dari bunga potong krisan. Aplikasi 1-MCP konsentrasi $0.7 \mu \mathrm{L} . \mathrm{L}^{-1}$ dengan waktu aplikasi 6 jam memberikan hasil yang signifikan memperpanjang umur bunga potong krisan yakni 22 hari apabila dibandingkan dengan kontrol yang hanya memiliki umur selama 6,67 hari. Hasil serupa ditemukan Mubarok (2012), aplikasi 1-MCP $0.25 \mu \mathrm{L} . \mathrm{L}^{-1}$ selama 6 jam pada krisan 'Yellow Fiji' mampu memperlambat perubahan warna bunga, pelayuan bunga dan memperpanjang kesegaran bunga potong.

Tabel 2. Pengaruh aplikasi 1-MCP pada komoditas sayur dan buah

\begin{tabular}{|c|c|c|c|c|c|c|}
\hline No & Jenis & Konsentrasi & Suhu & $\begin{array}{c}\text { Lama } \\
\text { aplikasi }\end{array}$ & Pengaruh & Referensi \\
\hline 1 & $\begin{array}{c}\text { Apel (Malus } \\
\text { domestica) } \\
\text { 'Fuji', 'Delicious', } \\
\text { 'Gala','Granny Smith' }\end{array}$ & $0.625 ; 1 \mu \mathrm{L} . \mathrm{L}^{-2}$ & $20^{\circ} \mathrm{C}$ & $18 \mathrm{jam}$ & $\begin{array}{l}\text { Mempertahankan } \\
\text { kekerasan buah dan } \\
\text { asam terlarut }\end{array}$ & Bai et al., 2005 \\
\hline 2 & $\begin{array}{l}\text { Brokoli (Brassica } \\
\text { oleracea) 'Maverick', } \\
\text { '886' dan 'Green Belt }\end{array}$ & $1 ; 12 \mu \mathrm{L} . \mathbf{I}^{-2}$ & $\begin{array}{c}5 ; 10 \\
20^{\circ} \mathrm{C}\end{array}$ & $\begin{array}{l}6 ; 12 ; 16 \\
\text { jam }\end{array}$ & $\begin{array}{c}\text { Menghambat } \\
\text { penguningan, mengurangi } \\
\text { tingkat respirasi dan } \\
\text { memperpanjang } \\
\text { kesegaran }\end{array}$ & $\begin{array}{l}\text { Able et al., } \\
2002\end{array}$ \\
\hline 3 & $\begin{array}{c}\text { Kiwi (Actinidia } \\
\text { deliciosa) 'Hayward' }\end{array}$ & $1 \mu \mathrm{L} \cdot 1^{-1}$ & $20^{\circ} \mathrm{C}$ & 24 jam & $\begin{array}{c}\text { Mempertahakan kekerasa } \\
\text { buah selama } \\
\text { penyimpanan hingga } 4 \\
\text { bulan }\end{array}$ & $\begin{array}{l}\text { Cantin et al., } \\
2011\end{array}$ \\
\hline 4 & $\begin{array}{c}\text { Lettuce (Lactuca } \\
\text { sativa) }\end{array}$ & $1 ; 0,1 \mu \mathrm{L} \cdot \mathrm{I}^{-2}$ & $6^{\circ} \mathrm{C}$ & 4 jam & $\begin{array}{c}\text { Menghambat } \\
\text { terbentuknya spot pada } \\
\text { daun, memperpanjang } \\
\text { kesegaran }\end{array}$ & $\begin{array}{c}\text { Blankenship et } \\
\text { al., } 2001\end{array}$ \\
\hline 5 & $\begin{array}{l}\text { Pak choy (Brassica } \\
\text { rapa var. chinensis) } \\
\text { 'Shanghai' }\end{array}$ & $12 \mu \mathrm{L} \cdot \mathrm{L}^{-1}$ & $10^{\circ} \mathrm{C}$ & 16 jam & $\begin{array}{c}\text { Mempertahankan } \\
\text { kesegaran setelah } \\
\text { aplikasi etilen, } \\
\text { mengurangi penguningan } \\
\text { daun }\end{array}$ & $\begin{array}{c}\text { Blankenship et } \\
\text { al., } 2001\end{array}$ \\
\hline 6 & $\begin{array}{c}\text { Papaya (Carica } \\
\text { papaya) }\end{array}$ & $25 \mu \mathrm{L} \cdot \mathrm{L}^{-2}$ & $20^{\circ} \mathrm{C}$ & 14 jam & $\begin{array}{c}\text { Memperlambat } \\
\text { pematangan buah, }\end{array}$ & $\begin{array}{c}\text { Blankenship et } \\
\text { al., } 2001\end{array}$ \\
\hline 7 & $\begin{array}{l}\text { Pir (Pyrus communis } \\
\text { L.) 'd Anjou' }\end{array}$ & $42 \mu \mathrm{mol} . \mathrm{m}^{-z}$ & $20^{\circ} \mathrm{C}$ & $12 \mathrm{jam}$ & $\begin{array}{c}\text { Mempertahankan tingkat } \\
\text { kekerasan buah selama } \\
\text { penyimpanan } 2 \text { dan } 4 \\
\text { bulan }\end{array}$ & $\begin{array}{l}\text { Argenta et al., } \\
2003\end{array}$ \\
\hline 8 & $\begin{array}{c}\text { Tomat (Lycopersicon } \\
\text { esculentum) 'Florida } \\
47 \text { ' }\end{array}$ & $10 \mu \mathrm{L} \cdot \mathrm{L}^{-1}$ & $5^{\circ} \mathrm{C}$ & 24 jam & $\begin{array}{l}\text { Tidak mempertahankan } \\
\text { kekerasan perikarp irisan } \\
\text { buah tomat setelah } \\
\text { penyimpanan }\end{array}$ & $\begin{array}{l}\text { Jeong et al., } \\
2004\end{array}$ \\
\hline
\end{tabular}

Penggunaan 1-MCP pada bunga potong dapat mengurangi kehilangan berat segar serta degradasi klorofil yang terjadi pada daun. Daun yang menguning pada bunga potong krisan merupakan respons umum terhadap peningkatan kadar etilen, dan bisa 
terjadi sesaat sebelum penuaan bunga (Doi et al. 2004). Penuaan pada bagian petal bunga serta kerusakan jaringan lainnya karena etilen mampu menghambat dari fungsi sel tanaman. Etilen mampu menghambat aktivitas sel tanaman dengan mengatur aquaporin yang merupakan jalur air antar sel tanaman. Penghambatan aquaporin akan menyebabkan kerusakan sel akibat kurangnya kebutuhan air bagi sel tanaman (Ma et al., 2008). Adapun pengaruh aplikasi 1-MCP pada beberapa jenis tanaman lain dan bahan tanam (Tabel 3).

Tabel 3. Pengaruh aplikasi 1-MCP pada komoditas tanaman hias dan bahan tanam

\begin{tabular}{|c|c|c|c|c|c|c|}
\hline No & Jenis & Konsentrasi & Suhu & $\begin{array}{l}\text { Lama } \\
\text { aplikasi }\end{array}$ & Pengaruh & Referensi \\
\hline 1 & Dianthus caryophyllus L. & $0.1 \mu \mathrm{L} \cdot \mathrm{L}^{-1}$ & $20^{\circ} \mathrm{C}$ & 6 jam & $\begin{array}{l}\text { Tidak berpengaruh dalam } \\
\text { memperpanjang kesegaran } \\
\text { bunga potong }\end{array}$ & $\begin{array}{l}\text { Burana et al., } \\
2015\end{array}$ \\
\hline 2 & $\begin{array}{l}\text { Eustoma grandiflorum } \\
\text { (Raf.) Shinn }\end{array}$ & $0.1 \mu \mathrm{L} \cdot \mathrm{L}^{-2}$ & $20^{\circ} \mathrm{C}$ & 6 jam & $\begin{array}{c}\text { memperpanjang kesegaran } \\
\text { bunga potong }\end{array}$ & $\begin{array}{l}\text { Burana et al., } \\
2015\end{array}$ \\
\hline 3 & $\begin{array}{c}\text { Geranium (Pelargonium } \\
\text { hortotum) 'Cotton } \\
\text { Candy', 'Kim', 'Veronica' }\end{array}$ & $0.1 \mu \mathrm{L} \cdot \mathrm{L}^{-1}$ & - & 1 jam & $\begin{array}{l}\text { Mengurangi tingkat absisi } \\
\text { petal bunga setelah } \\
\text { diaplikasikan etilen }\end{array}$ & $\begin{array}{l}\text { Jones et al., } \\
2001\end{array}$ \\
\hline 4 & $\begin{array}{c}\text { Krisan (Chrysanthemum } \\
\text { morifolium) 'Yellow Fiji' }\end{array}$ & $0.25 \mu \mathrm{L} \cdot \mathrm{I}^{-2}$ & - & 6 jam & $\begin{array}{l}\text { Memperlambat perubahan } \\
\text { warna bunga, pelayuan } \\
\text { bunga dan memperpanjang } \\
\text { kesegaran bunga potong }\end{array}$ & Mubarok,2012 \\
\hline 5 & $\begin{array}{c}\text { Krisan (Chrysanthemum } \\
\text { morifolium) }\end{array}$ & $0,7 \mu \mathrm{L} \cdot \mathrm{L}^{-2}$ & - & 6 jam & $\begin{array}{c}\text { Memperpanjang kesegaran } \\
\text { bunga potong }\end{array}$ & $\begin{array}{l}\text { Fahmy dan } \\
\text { Hassan, } 2005\end{array}$ \\
\hline 6 & $\begin{array}{c}\text { Sirih Belanda } \\
\text { (Epipremnum pinnatum) }\end{array}$ & $200 \mathrm{~nL} \cdot \mathrm{I}^{-1}$ & $20^{\circ} \mathrm{C}$ & 6 jam & $\begin{array}{c}\text { Menghambat penurunan } \\
\text { klorofil setelah } \\
\text { penyimpanan } 4 \text { hari }\end{array}$ & $\begin{array}{l}\text { Muller et al., } \\
1997\end{array}$ \\
\hline 7 & $\begin{array}{l}\text { Setek Begonia hibrida } \\
\text { 'Miss Murry' }\end{array}$ & $700 \mathrm{~nL} \cdot \mathrm{L}^{-1}$ & - & 4 jam & $\begin{array}{l}\text { Mengurangi jumlah akar } \\
\text { yang terbentuk }\end{array}$ & $\begin{array}{l}\text { Leatherwood et } \\
\text { al.,2016 }\end{array}$ \\
\hline 8 & $\begin{array}{c}\text { Setek Geranium } \\
\text { (Pelargonium hortotum) } \\
\text { 'Kardino' }\end{array}$ & $700 \mathrm{~nL} \cdot \mathrm{I}^{-1}$ & - & 4 jam & $\begin{array}{l}\text { Mengurangi tingkat absisi } \\
\text { daun setek, Tidak } \\
\text { mengurangi jumlah akar } \\
\text { yang terbentuk }\end{array}$ & $\begin{array}{l}\text { Leatherwood et } \\
\text { al.,2016 }\end{array}$ \\
\hline 9 & $\begin{array}{c}\text { Setek Hibiscus rosa- } \\
\text { sinensis }\end{array}$ & $200 \mathrm{~nL} \cdot \mathrm{L}^{-1}$ & $20^{\circ} \mathrm{C}$ & 6 jam & $\begin{array}{l}\text { Menghambat degradasi } \\
\text { klorofil selama } \\
\text { penyimpanan }\end{array}$ & $\begin{array}{l}\text { Serek et al., } \\
1998\end{array}$ \\
\hline 10 & $\begin{array}{l}\text { Setek krisan 'Coral } \\
\text { Charm' }\end{array}$ & $200 \mathrm{~nL} \cdot \mathrm{L}^{-1}$ & $20^{\circ} \mathrm{C}$ & 6 jam & $\begin{array}{c}\text { Tidak menghambat } \\
\text { degradasi klorofil selama } \\
\text { penyimpanan, } \\
\text { menghambat pertumbuhan } \\
\text { akar }\end{array}$ & $\begin{array}{l}\text { Serek et al., } \\
1998\end{array}$ \\
\hline 11 & Setek krisan & $700 \mathrm{~nL} \cdot \mathrm{I}^{-1}$ & - & 4 jam & $\begin{array}{c}\text { Menghambat degradasi } \\
\text { klorofil selama } \\
\text { penyimpanan dan } \\
\text { menghambat pertumbuhan } \\
\text { akar }\end{array}$ & $\begin{array}{l}\text { Leatherwood dan } \\
\text { Dole, } 2007\end{array}$ \\
\hline
\end{tabular}


Aplikasi 1-MCP pada setek krisan. Dalam budidaya krisan, umumnya perbanyakan dilakukan secara vegetatif yakni dengan setek batang (Zhang et al, 2013; Budiarto dan Marwoto, 2007). Dengan metode perbanyakan ini, produksi tanaman dengan sifat yang homogen dalam jumlah banyak dapat tercapai (El-Eslamboly, 2014). Pada budidaya krisan bunga potong, hasil pembungaan dari tanaman krisan sangat dipengaruhi oleh kualitas dari benih setek. Sehingga kualitas setek krisan perlu diperhatikan dalam produksi tanaman krisan yang baik (Istianingrum et al., 2013).

1-MCP digunakan untuk menjaga kualitas dari setek krisan saat dilakukan pengiriman jarak jauh. Setek dapat beresiko terpapar oleh etilen endogen ataupun eksogen selama pengiriman. Selama distribusi, lama penyimpanan selama distribusi akan mempengaruhi tanaman akibat adanya bertambahnya konsentrasi etilen yang membuat efeknya semakin kuat seiring bertambah lamanya waktu distribusi. Konsentrasi etilen akan terus meningkat di sekitar tanaman selama penyimpanan dilakukan terlebih pada suhu ruang $\left(20-25^{\circ} \mathrm{C}\right)$ (Enfield, 2011). Gejala yang ditimbulkan dari paparan etilen pada setek dapat berupa penguningan pada daun, absisi atau penguguran daun, dan nekrosis (lqbal et al., 2017).

Pada beberapa penelitian, penggunaan 1-MCP dapat mengurangi efek etilen pada proses penuaan dan kerusakan setek. Penelitian Serek et al. (1998) mengungkapkan aplikasi 1-MCP $200 \mathrm{~nL} \cdot \mathrm{L}^{-1}$ selama 6 jam tidak berpengaruh signifikan dalam menjaga kualitas setek krisan dibandingkan dengan kontrol. Aplikasi 1-MCP $200 \mathrm{~nL} \cdot \mathrm{L}^{-1}$ pada setek krisan tercatat mengurangi jumlah akar dan panjang akar saat dilakukan penanaman. Hasil berbeda diungkapkan Leatherwood dan Dole (2007), bahwa aplikasi $700 \mathrm{~nL} \cdot \mathrm{L}^{-1} 1$ MCP selama 4 jam pada 55 jenis tanaman herbasius berdampak mengurangi kerusakan akibat paparan etilen pada konsentrasi $0,100 \mathrm{~nL} \cdot \mathrm{L}^{-1}$, dan $1000 \mathrm{~nL} \cdot \mathrm{L}^{-1}$. Diketahui dari penelitian tersebut, 28 dari 55 tanaman dapat ditekan kerusakannya akibat etilen dengan aplikasi 1-MCP. Aplikasi 1-MCP dapat menjadi cara untuk mengurangi kerusakan bahan setek dari efek etilen pada setek Chrysanthemum dan Hibiscus saat didalam penyimpanan dan pengangkutan, namun aplikasi 1-MCP dapat mengurangi kemampuan setek untuk membentuk akar. Menurut Klerk dan Hanecakova (2008) bahwa etilen berperan dalam tahap awal inisiasi akar. Sehingga dengan adanya aplikasi 1-MCP pada setek akan menghambat pembentukan akar karena peran etilen terhadap setek dihambat.

\section{$4 \quad$ Kesimpulan}

1-Methylcyclopropene (1-MCP) dapat digunakan sebagai etilen inhibitor dengan cara kerja menjadi kompetitor etilen saat menempel pada reseptor. Faktor yang mempengaruhi efek penggunaan 1-MCP yakni jenis komoditas, tingkat perkembangan 
dari tanaman, konsentrasi 1-MCP, temperatur lingkungan saat aplikasi, dan lama aplikasi 1-MCP. Aplikasi 1-MCP pada bunga potong krisan dapat mempertahankan kesegaran dengan memperlambat kelayuan bunga dan perubahan warna bunga. Penggunaan 1MCP dapat mengurangi degradasi klorofil pada daun, kehilangan berat segar bunga. Aplikasi 1-MCP $700 \mathrm{~nL} \cdot \mathrm{L}^{-1}$ pada setek krisan mampu mengurangi penguningan daun atau absisi daun. Pada konsentrasi yang lebih rendah, 1-MCP $200 \mathrm{~nL} \cdot \mathrm{L}^{-1}$ tidak memberikan pengaruh dalam mempertahankan kualitas setek. Aplikasi 1-MCP akan menghambat pembentukan akar pada setek.

\section{Daftar pustaka}

Able, A.J., Wong, L.S., Prasad, A., O'Hare, T.J. (2002). 1-MCP is more effective on a floral brassica (Brassica oleracea var. italica L.) than a leafy brassica (Brassica rapa var. chinensis). Postharvest Biology and Technology 26, 147-155

Afiifah, D., Sutari, W., Kusumiyati, Suminar, E., \& Mubarok. (2017). Efektivitas 1Methylcyclopropene (1-MCP) terhadap ketahanan simpan bunga potong mawar (Rosa hybrida Hort.). Kultivasi, 16(1), 293-297.

Agarwal, G., Choudhary, D., Singh, V.P., \& Arora, A. (2012). Role of ethylene receptors during senescence and ripening in horticultural crops. Plant Signaling and Behavior, 7, 827-846.

Argenta, L.C., Fan, X., Mattheis, J.P. (2003). Influence of 1-Methylcyclopropene on ripening, storage life, and volatile production by d'Anjou cv. pear fruit. J. Agric. Food Chem. 51, 3858-3864

Bai, J., Baldwin, E.A., Goodner, K.L., Mattheis, J.P., Brecht, J.K. (2005). Responses of four apple cultivars to 1-Methylcyclopropene treatment and controlled atmosphere storage. Hort Science 40 (5), 1534-1538

Blankenship, S. (2001). Ethylene effects and the benefits of 1-MCP. Perishables Handling Quarterly, 108, 2-4.

Blankenship, S.M., \& Dole, J.M. (2003). 1-Methylcyclopropene : a review. Postharvest Biology and Technology 28, 1-25.

Bleecker, A.B., \& Kende, H. (2000). Ethylene: a gaseous signal molecule in plants. Annu. Rev. Cell Dev. Biol.16,1-18.

Budiarto, K., \& Marwoto, B. (2007). Produksi tanaman induk dan kualitas stek varietas krisan di rumah plastik dan lahan terbuka. J. Hort, 17(4), 321-327.

Burana, C., Kurokura, T., \& Yamane, K. (2015). Short-term controlled atmosphere and 1MCP effects on the vase life of cut flowers. Proc. XI th Int. Controlled and Modified Atmosphere Research Conf. Acta Hort. 1071, 635-640.

Cantin, C.M., Holcorft, D., Crisosto, C.H. (2011). Postharvest application of 1Methylcyclopropene (1-MCP) extends shelf life of kiwifruit. Acta Hort 913, 621-626

Doi, M., Aoe, K., Watabe, S., Inamoto, K., \& Imanishi, H. (2004). Leaf yellowing of cut standard chrysanthemum (Dendranthema grandiflora Kitamura) 'Shuho-no-chikara' induced by ethylene and postharvest increase in ethylene sensitivity. Journal of the Japanese Society for Horticultural Science 73, 229-234.

Enfield, A. (2011). Influence of the postharvest environment on the storage potential and propagation performance of unrooted cuttings of herbaceous ornamentals. All dissertations paper 792 Clemson University. 
ISSN 2354-7251 (print)

El-Eslamboly, A. A. S. A. (2014). Effect of watermelon propagation by cutting on vegetative growth, yield and fruit quality. Egypt. J. Agric. Res 92 (2): 553-578.

Fahmy, A.E.R., \& Hassan, S. (2005). Postharvest studies on some important flower crops. Diakses tanggal 3 maret 2018, dari www.lib.uni-corvinus.hu/Phd/Sadek-hassan.

Feng, X.Q., Apelbaum, S., Sisler, E.C., \& Goren, R. (2004). Control of ethylene activity in various plant systems by structural analogues of 1-methylcyclopropene. Plant Growth Regul 42, 29-38.

Howe, P.D., \& Dobson, S. (2002). Silver and Silver Compounds: Environmental Aspects. Concise International Chemical Assessment Document 44, World Health Organization.

Istianingrum, P., Damanhuri., \& Soetopo, L. (2013). Pengaruh generasi benih terhadap pertumbuhan dan pembungaan krisan (Chrysanthemum) varietas Rhino. Jurnal Produksi Tanaman Vol. 1(3), 1-8.

lqbal, N., Khan, N.A., Ferrante, A., Trivellini, A., Francini, A., \& Khan, MIR. (2017). Ethylene role in plant growth, development and senescene : interaction with othe phytohormones. Frontiers in Plant Science, 8(475), 2-19.

Jeong, J., Brecth, J.K., Huber, D.J., Sargent, S.A. (2004). 1-Methylcyclopropene (1-MCP) for maintaining texture quality of fresh-cut tomato. Hort Science 39 (6), 1359-1362.

Jones, M.L., Kim, E.S., Newman, S.E. (2001). Role of ethylene and 1-MCP in flower development and petal abscission in zonal geraniums. Hort Science 36 (7), 13051309.

Klerk, G.J.D., \& Hanecakova, J. (2008). Ethylene and rooting of mung bean cuttings. The role of auxin induced ethylene synthesis and phase-dependent effects. Plant Growth Regul 56, 203-209.

Leatherwood, W.R., Dole, J.M., Bergmann, B.A., Faust, J.E. (2016). 1-Methycyclopropene improves ethylene tolerance of unrooted herbaceous cuttings but delays adventitious root development in Angelonia, Calibrachoa, Impatiens, Portulaca, Sutera, and Verbena cultivars. Hort Science 51 (2), 164-170.

Leatherwood, W.R., \& Dole, J.M. (2007). Ethylene sensitivity of unrooted cuttings from 28 genera and effectiveness of 1-MCP to prevent ethylene damage. Special research report postharvest physiology.

Ma, N., Xue, J. Q., Li, Y. H., Liu, X. J., Dai, F. W., \& Jia, W. S. (2008). RhPIP2;1, a rose aquaporin gene, is involved in ethylene-regulated petal expansion. Plant Physiol. 148, 894-907. doi: 10.1104/pp.108.120154.

Ma, Y.P., Chen, M.M., Wei, J.X., Zhao, L., Liu, P.L., Dai, S.L., \& Wen, J. (2016). Origin of Chrysanthemum cultivars-evidence from nuclear low-copy LFY gene sequences. Biochemical Systematics and Ecology 65, 129-136.

Mirjalili, S.A. (2015). Assessment of concurrent of the sucrose and silver nitrate on cut flower of rose (Rosa hybrida cv. 'Red One'). Journal of Biodiversity and Environmental Sciences (JBES), 6(1), 122-126.

Mubarok, S. (2012). Kualitas bunga krisan potong 'Yellow Fiji' sebagai respon dari aplikasi 1-Methylcyclopropene. J. agrivigor 11 (2), 244-250.

Mubarok, S., Serek, M., \& Mussmann, V. (2011). Efficacy of New Formulation of 1Methylcyclopropene for Improving Postharvest Quality of Pelargonium Flower. Proceeding International Conference on Sustainable Agriculture and Food Security. 27-28.

Narumi, T., Kanno, Y., Suzuki, M., Kishimoto, S., Ohmiya, A., \& Satoh, S. (2005). Cloning 
of a cDNA encoding an ethylene receptor (DG-ERS1) from Chrysanthemum and comparison of its mRNA level in ethylene-sensitive and -insensitive cultivars. Postharvest Biol Technol 36, 21-30.

Pusat Data dan Sistem Informasi Pertanian. (2014). Outlook Komoditi Krisan. Sekretariat Jenderal-Kementrian Pertanian.

Salaun, J., \& Baird, M.S. (1995). Biologically active cyclopropanes and cyclopropenes. Curr. Med. Chem. 2, 511-542.

Setyadjit., Sukasih, E., \& Permana, A.W. (2012). Aplikasi 1-MCP dapat memperpanjang umur segar komoditas hortikultura. Buletin Teknologi Pascananen Pertanian, 8(1), 27-34.

Serek, M., Prabucki, A., Sisler, E.C., \& Andersen, A.S. (1998). Inhibitors of ethylene action affect final quality and rooting of cuttings before and after storage. Hort Science, 33(1), 153-155.

Serek, M., Woltering, E.J., Sisler, E.C., Frello, S., \& Sriskandarajah, S. (2006). Controlling ethylene responses in flowers at the receptor level. Biotechnology advances, 24, 368-381.

Singh, P., \& Chettri, R. (2013). A new propagation method for rapid multiplication. Int J. Conserv Sci 4(1), 95-100.

Silva, T.D. (2003). Chrysanthemum organogenesis through thin cell layer technology and plant growth regulator control. Asian journal of plant science 2 (6), 505-514.

Silva, T.D. (2006). Ornamental Cut Flowers: Physiology in Practice. Floriculture, Ornamental and Plant Biotechnology Volume I, Global Science Books, UK.

Syifaurrahmah, A. (2011). Pengelolaan panen dan pasca panen bunga krisan potong di PT. Alam Indah Bunga. Departemen Agronomi dan Hortikultura .Bunga Krisan Potong di PT . Alam Indah Bunga Nusantara, Cipanas Cianjur Jawa Barat.

Watkins, C.B. (2006).The use of 1-methylcyclopropene (1-MCP) on fruits and vegetables. Biotechnology Advances 24, 389-409.

Zhang, J., Chen, S., Liu, R., Jiang, J., Chen, F., \& Fang, W. (2013). Chrysanthemum cutting productivity and rooting ability are improved by grafting. The Scientific World Journal 2013. 